\title{
Predicting Behavioral Intention of Rural Inhabitants toward Economic Incentive for Deforestation in Gilgit-Baltistan, Pakistan
}

\author{
Saif Ullah ${ }^{1}$, Ali Abid ${ }^{1}\left(\right.$, Waqas Aslam ${ }^{1}$, Rana Shahzad Noor ${ }^{2} \oplus$, Muhammad Mohsin Waqas ${ }^{3}$ \\ and Tian Gang $1, *$ (D) \\ 1 College of Economics and Management, Northeast Forestry University, Harbin 150040, China; \\ ranasaif2014@outlook.com (S.U.); ali.abid@uaar.edu.pk (A.A.); aslam_waqas219@yahoo.com (W.A.) \\ 2 Department of Agriculture, Biological, Environment and Energy Engineering, College of Engineering, \\ Northeast Agricultural University, Harbin 150030, China; engr.rsnoor@uaar.edu.pk \\ 3 Department of Agricultural Engineering, Khwaja Fareed University of Engineering and \\ Information Technology, Rahim Yar Khan 64200, Pakistan; mohsinwaqas333@gmail.com \\ * Correspondence: tiangang0451@nefu.edu.cn; Tel.: +86-189-4605-9819
}

Citation: Ullah, S.; Abid, A.; Aslam, W.; Noor, R.S.; Waqas, M.M.; Gang, T. Predicting Behavioral Intention of Rural Inhabitants toward Economic Incentive for Deforestation in Gilgit-Baltistan, Pakistan. Sustainability 2021, 13, 617. https:// doi.org/10.3390/su13020617

Received: 1 December 2020 Accepted: 6 January 2021 Published: 11 January 2021

Publisher's Note: MDPI stays neutral with regard to jurisdictional clai$\mathrm{ms}$ in published maps and institutional affiliations.

Copyright: (C) 2021 by the authors. Licensee MDPI, Basel, Switzerland. This article is an open access article distributed under the terms and conditions of the Creative Commons Attribution (CC BY) license (https:// creativecommons.org/licenses/by/ $4.0 /)$.

\begin{abstract}
The conservation of forest in the northern areas of Pakistan is the major priority of the national environmental policy to fight against global warming. Despite the policy for the protection of forest, rural residents' behavior toward economic incentives for deforestation may undermine their conservation goals. Therefore, the purpose of this study was to understand the factors that affect the illegal behaviors related to deforestation in the northern areas of Pakistan. The present study applied the socio-psychological theory of planned behavior to predict the behavioral intention of rural residents toward economic incentives for deforestation. Correlations were explored between background factors toward motivations for deforestation based on positive and negative views through open-ended questions. Attitude and descriptive norm were found good predictors to perceive the behaviors. The findings of the study suggest that rural communities' support for compliance with policies is vital for the long-term efficacy and protection of the forest in the region. Further, change in the behaviors of inhabitants toward the ecosystem through training can be improved to manage the forest.
\end{abstract}

Keywords: forest conservation; forest management; rural residents; economic incentives; Pakistan

\section{Introduction}

Globally, forests have been receiving ever-growing attention to fight against global warming. Forest not only conserves biodiversity but also provides necessary ecosystem services to society. Nevertheless, recently several studies have demonstrated that restrictions on the use of natural resources have negative behavior among the rural residents who rely on the forest for their livelihood, which creates a lot of hurdles for the management of forests [1-5]. The mountainous rural area resident's major source of income is from the forest resources; therefore, the economic incentive from forests directs rural residents toward deforestation [6-12]. Therefore, comprehensive attention is needed to understand the relationship between rural residents, economic incentives, and forest conservation.

Scientific literature has explored the relationship between rural residents and deforestation [13-16]. Such literature has helped to identify the preferences and beliefs of residents on conservation issues [17]. Therefore, the evaluation of plausible relationships with intentions is important to predict the actions that influence and change the behavior of rural communities [18-21]. In the past, many scholars have suggested incorporating the beliefs of rural residents toward the conservation of natural resources in global forest policy [22-25]. 
According to the National Forest Policy of Pakistan 2015, the lawmakers have taken steps to manage forests and improve public awareness of the ecological and cultural values of forests [26-29]. Nevertheless, forests have been weakly preserved in recent years and it is a challenging task in northern areas of Pakistan to apply strict rules of preservation due to the high reliance of peoples on the natural resources of forests [30-32]. In the scarcely facilitated area of Gilgit-Baltistan, resident depends on natural resources for their livelihoods [32,33]. According to Reference [32], porters cut trees for cooking, walking sticks, and fuel. This is because people have no source of income in the region, and they used natural resources to fulfill their basic needs; therefore, policies regarding the conservation of forests adversely affect the behavior of rural inhabitants. In the northern areas of Pakistan, rural resident's relationships with the forest authorities and continuous illegal activities to use fuel-wood are of particular concern for deforestation. This is due to the existence of strong (informal) links between the authorities, influential groups, and timber mafia $[34,35]$. The increasing level of illegal activities also negatively affects the rest of the areas. Deforestation in the developed countries is considered due to expansion in agricultural land [36-42]. While in the case of developing countries like Africa, deforestation is continued for subsistence agriculture farming and wood production for local markets [43,44]. Agriculture and charcoal production are the main causes of deforestation in Tanzania [45] and fuel-wood in Senegal [46]. In Turkey, the main causes of deforestation are rapid urbanization and industrialization [47].

Previous studies related to deforestation in Pakistan are mainly focused on timber production, conversion to agriculture, roadbuilding, and human-caused fire [48]. According to the studies of Ullah et al. [14,49] and Ali et al. [14,49], deforestation in northern areas is due to the construction of roads and high population growth in the last few years. However, to the best knowledge of authors, no research has so far been conducted to examine the behavior of rural residents toward deforestation, especially the study related to the economic motivation of rural residents. Therefore, the purpose of this study is to investigate the intention of people toward economic incentives to control deforestation and help the government institutes to make effective policies for the livelihoods of rural residents as for as law enforcement agencies.

To perceive human behavior, Ajzen's theory of planned behavior, an extension of the theory of reasoned action, has been used [50]. Nonetheless, few studies on forest biodiversity have utilized such frameworks to analyze multiple predictors of behavior. [18]. According to the theory, the behavioral intentions arise from an individual's attitude (ATT), norms, and Planned Behavior Constructs (PBC), which can further be predicted by actual behavior in question [50]. Furthermore, a number of background factors including socioeconomic, knowledge, education, and past experience of the individual can influence the ATT, Normative (N), and PBC. [51]. Contextual aspects such as rules and legislation of government may often interfere and evaluate a behavior [52]. Attitude is defined as the extent to which an individual has a favorable or unfavorable view of a particular behavior. Descriptive normative (DN) is defined as the opinions of the people rather than what approve or disapprove by others [18,53]. PBC is the perception of how an individual feels ease or difficulty to perform a specific behavior $[50,54,55]$. Understanding behavioral intent toward, and factors that affect, illegal behaviors can help managers emphasize their actions to enhance people's compliance with laws and protect forest within those areas.

Therefore, our study investigated the ATT, DN, PBC, and Behavior Intention (BI) of the rural inhabitants toward their economic incentive for deforestation. By applying the theory of planned behavior, the purpose of the present study was to (a) identify background factors that may influence the intention of rural residents; (b) identify inhabitants' attitudes, descriptive norms, perceived behavioral control toward economic incentives for deforestation; and (c) identify rural inhabitant's illegal behavior toward the economic incentives for deforestation. 


\section{Theoretical Model}

\subsection{Theory of Planned Behavior}

Many contemporary studies have used intentions as a key component to understand the behavior in question [50,56-60]. In psychology, the theory of planned behavior is an attempt to shape an individual's behavioral intentions with a combination of three factors: attitudes toward the behavior, norms, and perceived behavioral control [51,61,62] as given in Figure 1.

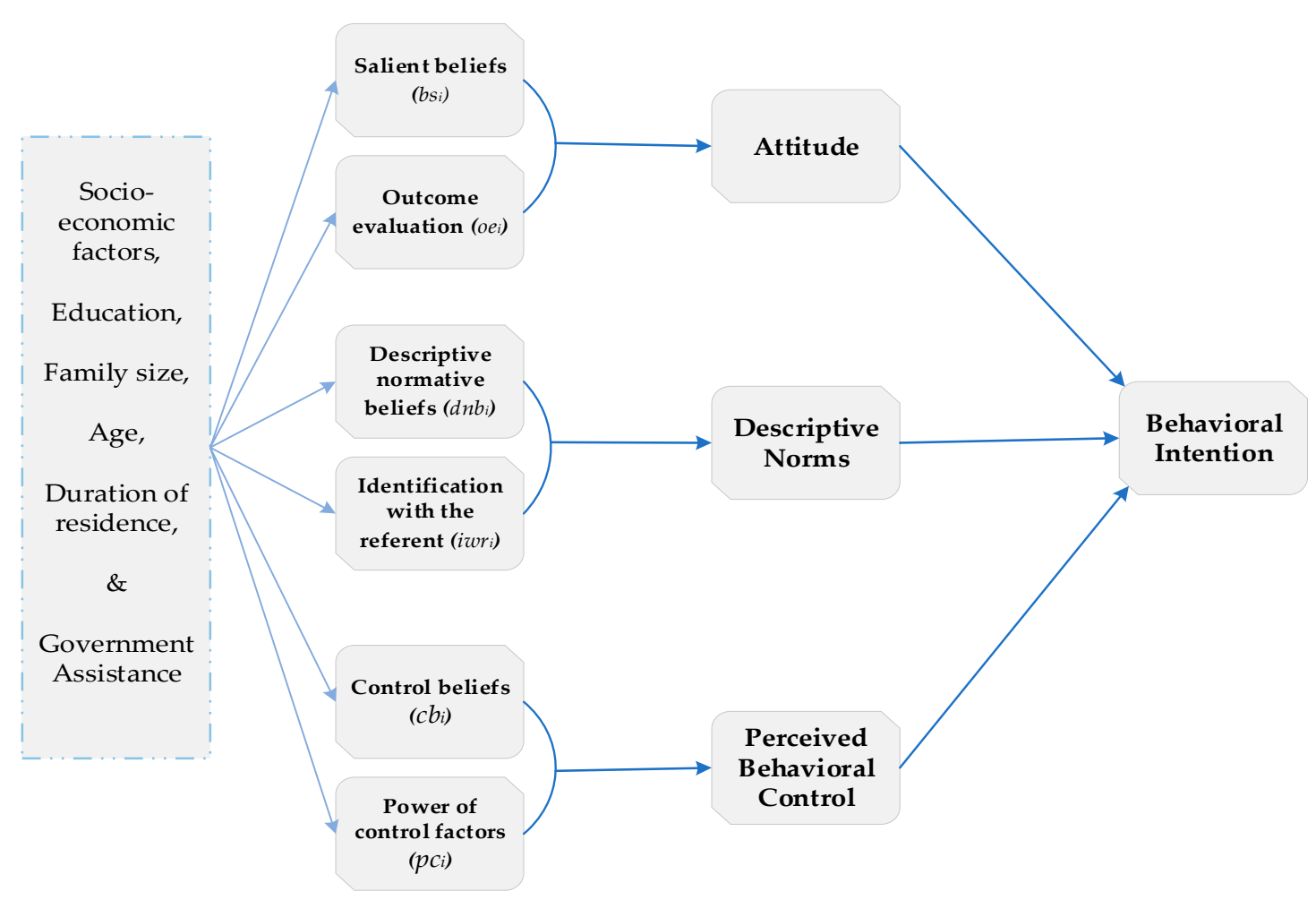

Figure 1. Factors affecting the Behavior Intention: Theory of Planned Behavior Model [50].

\subsection{Expectancy-Value Model}

The theory of planned behavior follows an expectancy-value model to predict the behavior of individual under question $[50,51,63,64]$. The beliefs-based measures are probably regarded to get a more accurate prediction of cognitive intention than its direct predictors alone.

The attitude is comprised of (silent beliefs $-\mathrm{bs}_{\mathrm{i}}$ ) and evaluation of the outcomes $\left(\mathrm{oe}_{\mathrm{i}}\right)$ and it can be obtained according to the following formula:

$$
\operatorname{ATT} \alpha \sum \mathrm{bs}_{\mathrm{i}} \mathrm{oe}_{\mathrm{i}}
$$

Strength of behavioral belief $\left(\mathrm{bs}_{\mathrm{i}}\right)$ is described as a possibility that can produce a particular outcome by performing a behavior (i) and the outcome evaluation $\left(\mathrm{oe}_{\mathrm{i}}\right)$ can be termed as the utility obtained if the result (i) occurs [50,51,63,64].

The descriptive norm (DN) describes the whereas descriptive norms refer to perceptions that others are or are not performing the behavior. Normative beliefs can be explored by assessing a person's identification with the referent $\left(\mathrm{iwr}_{\mathrm{i}}\right)$, multiplying the measures of descriptive normative beliefs $\left(\mathrm{dnb}_{\mathrm{i}}\right)$ regarding given referents by the corresponding identity measures, and then summing the normative belief by identity products $[65,66]$. A belief-based measure of the descriptive norm (DN) can be obtained according to the following formula:

$$
\mathrm{DN} \alpha \sum \mathrm{dnb}_{\mathrm{i}} \mathrm{iwr}_{\mathrm{i}}
$$


Strength of descriptive norms is formed by considering multiple descriptive normative beliefs $\left(\mathrm{dnb}_{\mathrm{i}}\right)$, or beliefs that behavior is normative for peers and individuals we look up to in social groups $[65,66]$.

“Perceived behavioral control-This refers to a person's perception of the ease or difficulty to perform the behavior of interest. It consisted of personal control beliefs $\left(\mathrm{cb}_{\mathrm{i}}\right)$ and the perceived strength of these specific control factors to facilitate or impede actions (power to affect- $\mathrm{pc}_{\mathrm{i}}$ ) $[50,67,68]$.

$$
\mathrm{PBC} \alpha \sum \mathrm{cb}_{\mathrm{i}} \mathrm{pc}_{\mathrm{i}}
$$

The strength of each control belief $\left(\mathrm{cb}_{\mathrm{i}}\right)$ is weighted by the perceived power $\left(\mathrm{pc}_{\mathrm{i}}\right)$ of the control factor to perform a specific behavior [50,51].

Behavioral intention (BI) refers to "a person's subjective probability that he will perform some behavior". BI is the function of three antecedents, namely, attitude, norms, and PBC. By incorporating the belief-based measures, BI can be calculated according to the following formula:

$$
\mathrm{BI}=\beta_{1} \mathrm{ATT}+\beta_{2} \mathrm{DN}+\beta_{3} \mathrm{PBC}+\varepsilon
$$

$\beta_{1}, \beta_{2}$, and $\beta_{3}$ are the coefficients to evaluate each component, and $(\varepsilon)$ is an error term.

\section{Materials and Methods}

\subsection{Study Area}

The present study was conducted in the three districts (Skardu, Gilgit, and Astore) of Gilgit-Baltistan, Pakistan (Figure 2), where rural residents not only use forest resources to meet their livelihood but also generate substantial cash income through trade in forest products.

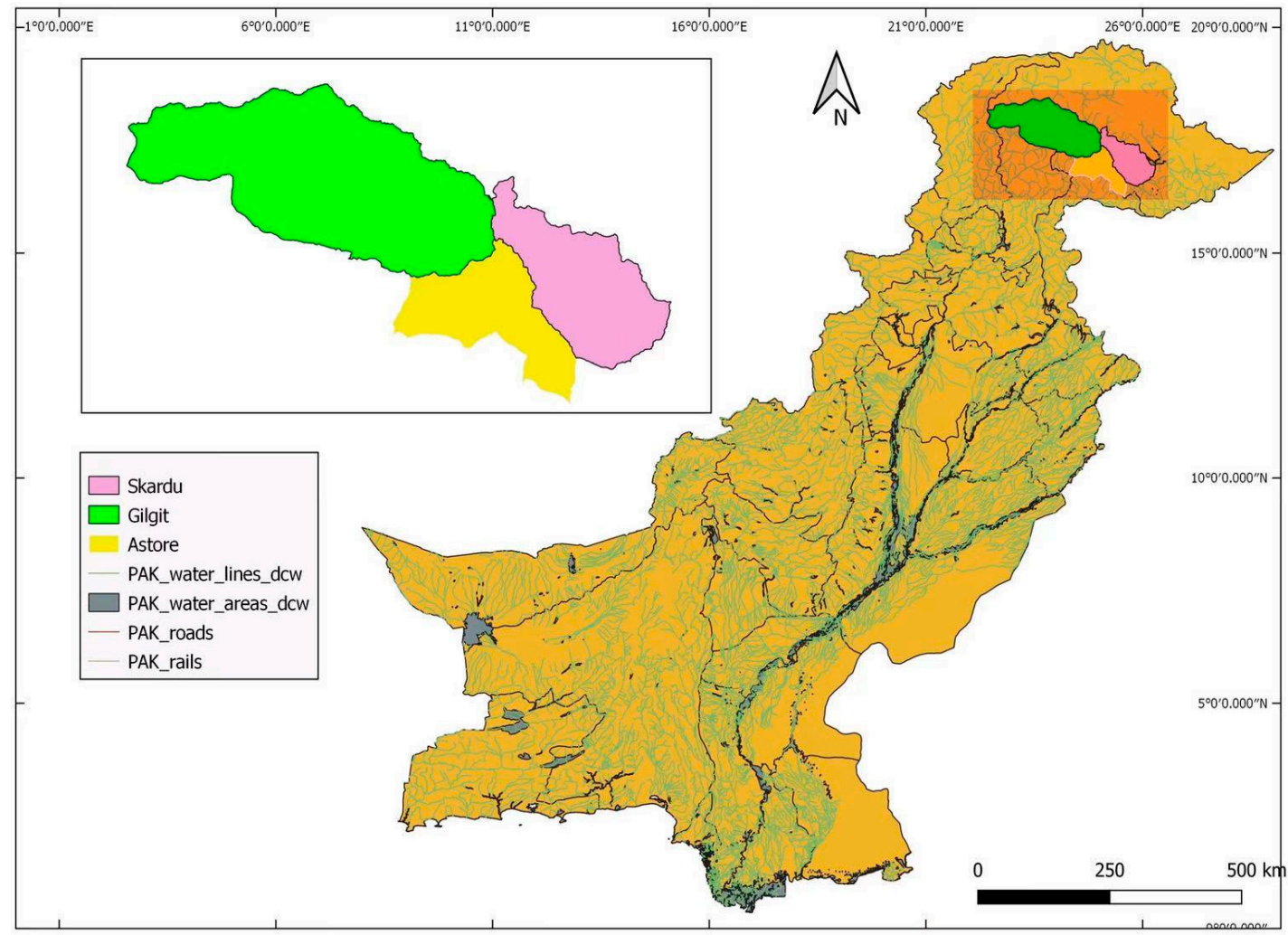

Figure 2. Study map. 


\subsection{Data Collection}

For the present study, survey data were collected from January 2019 to April 2019 (Figure 3). Face-to-face interviews were conducted with the residents. All the meetings were scheduled with the consent of the participants and their privacy was ensured.

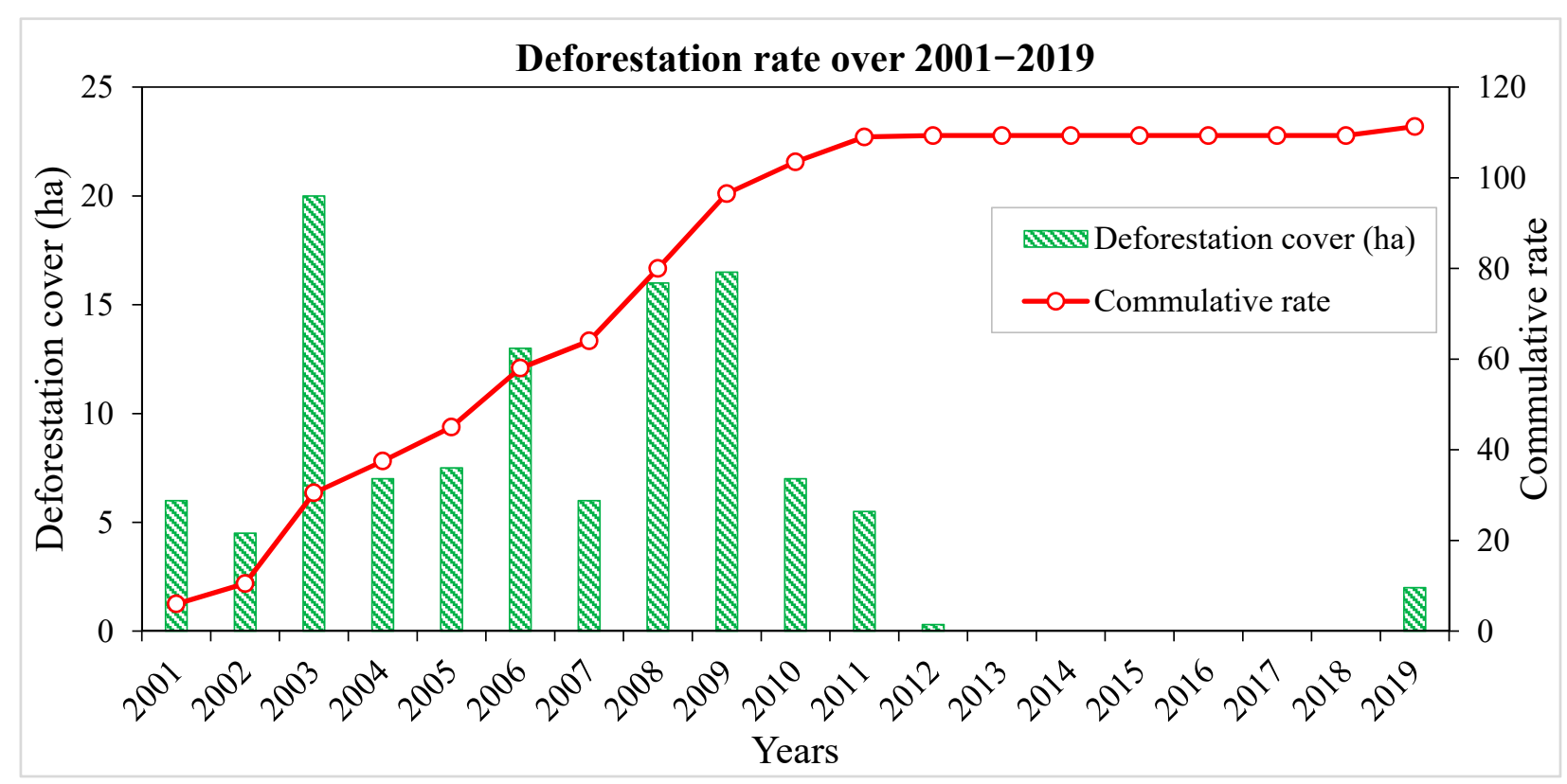

Figure 3. Continuous decline in forest cover area in northern Pakistan from 2001 to 2019. (Taken from https://www. globalforestwatch.org/dashboards/country/PAK).

From 2001 to 2019, Northern Areas lost 112 ha of tree cover, equivalent to a $0.23 \%$ decrease in tree cover since 2000. The survey also consisted of some close-ended questions of (a) socioeconomic factors: age, education, time duration to stay in the region, family size, and support from the government ("royalty" income offered to local residents for not utilizing the forest), (b) attitudes toward economic incentives for deforestation; descriptive norms defined in the study as the opinions of other people's behavior toward deforestation; perceived behavioral control as the respondent's views about the presence of law enforcement in the region; and behaviors toward economic incentives for deforestation. Moreover, an open-ended questionnaire has been used to explore the perceptions of the respondents on natural resources including the one where they lived. Categorization of these opinions was done according to the values of nature described by Kellert [69-71]. The opinions of the respondents were categorized into only two groups of natural values "(moralistic values, which represent a respect to the nature; and utilitarian values, which represents the material benefits that a person obtain from nature; Kellert, 2005)".

\subsection{Measurement of Variables}

Behavioral intention was defined for this research as the intention of rural residents toward the economic incentive of deforestation by replacing small-scale agriculture. The question was designed as follows: Do you have the intention to replace secondary forest with small-scale agriculture to get economic incentives? To evaluate the construct, a five-point bipolar Likert scale was used ranging from 4-very likely to 0-very unlikely.

Attitude was measured directly by utilizing five points "bipolar Likert scale ranging from very unlikely (0) to very likely (4)". For assessment of attitude, question was formed as follows: Do you think forest should be replaced with small-scale agriculture to get economic incentives? For the indirect assessment of belief-based items, (b) were measured on five points "Likert scale ranging from strongly disagree (0) to strongly agree (4)", while for (e) very important (4) to not very important (0). For the belief-based measures, 
three behavioral beliefs were presented to the respondents concerning that rural residents think by replacing forest with small-scale agriculture will provide food for the family, increase livelihood, and increase tourism (see Table 1).

Table 1. Items used for evaluation of Theory of Planned Behavior constructs.

\begin{tabular}{|c|c|c|}
\hline Behavioral Intention & \multicolumn{2}{|c|}{$\begin{array}{l}\text { Do you have the intention to replace secondary forest with small-scale agriculture to get } \\
\text { economic incentives? }\end{array}$} \\
\hline Attitude & \multicolumn{2}{|c|}{$\begin{array}{l}\text { Do you think forest should be replaced with small-scale agriculture to get } \\
\text { economic incentives? }\end{array}$} \\
\hline Descriptive Norm & \multicolumn{2}{|c|}{$\begin{array}{l}\text { Do you think that rural residents in the area replacing the forest with small-scale agriculture } \\
\text { for economic incentives? }\end{array}$} \\
\hline Perceived Behavioral Control & \multicolumn{2}{|c|}{ In my view, law enforcement is sufficient in the regions to control rural resident's activities? } \\
\hline \multicolumn{3}{|c|}{ Indirect evaluation of Theory of Planned Behavior constructs } \\
\hline \multirow{5}{*}{ ATT $\alpha \sum \mathrm{bs}_{\mathrm{i}} \mathrm{Oe}_{\mathrm{i}}$} & Salient beliefs $\left(\mathrm{bs}_{\mathbf{i}}\right)$ & Outcome evaluation $\left(\mathrm{oe}_{\mathrm{i}}\right)$ \\
\hline & \multicolumn{2}{|c|}{ Rural residents think by replacing forest with small-scale agriculture will ... } \\
\hline & ... provide foods for family & For me, food for family is ... \\
\hline & ... increase livelihood & For me, revenue is ... \\
\hline & ... increase tourism & For me, tourism is ... \\
\hline \multirow[b]{2}{*}{$\mathrm{DN} \alpha \sum \mathrm{dnb}_{\mathrm{i}} \mathrm{iwr}_{\mathrm{i}}$} & Descriptive normative beliefs $\left(\mathrm{dnb}_{\mathrm{i}}\right)$ & Identification with the referent $\left(\mathrm{iwr}_{\mathrm{i}}\right)$ \\
\hline & In my view people deforest in the region. & $\begin{array}{l}\text { With regards to deforestation, I am not similar } \\
\text { to people. }\end{array}$ \\
\hline \multirow{3}{*}{$\mathrm{PBC} \propto \sum \mathrm{cb}_{\mathrm{i}} \mathrm{pc}_{\mathrm{i}}$} & Control beliefs $\left(\mathrm{cb}_{\mathbf{i}}\right)$ & Power of control factors $\left(\mathrm{pc}_{\mathrm{i}}\right)$ \\
\hline & $\begin{array}{l}\text { I think legislation is insufficient to control } \\
\text { people's activities in the region. }\end{array}$ & $\begin{array}{l}\text { Without legislation, it is more difficult to } \\
\text { control people's activities in the region. }\end{array}$ \\
\hline & $\begin{array}{l}\text { I think training of personnel is unsuited } \\
\text { to control people's activities in the region. }\end{array}$ & $\begin{array}{l}\text { Without proper training, it is more difficult to } \\
\text { control illegal activities in the region. }\end{array}$ \\
\hline
\end{tabular}

Talking about the actions of others (descriptive norms) was found more comfortable for the respondent than perceived social pressure from others for an individual to behave in a certain manner (subjective norms). Descriptive norm was measured directly by utilizing a five-point unipolar Likert scale ranging from not at all (0) to a large extent (4). The item was designed as follows: Do you think that rural residents in the area replacing the forest with small-scale agriculture for economic incentives? The indirect assessment of belief-based items $\left(\mathrm{dnb}_{\mathrm{i}}\right)$ was performed by using unipolar Likert scale, from 0 - strongly disagree to 4 strongly agree, while for (iwr $\left.\mathrm{r}_{\mathrm{i}}\right)$ " unipolar Likert scale was used ranging from 0 — strongly disagree to 4-strongly agree".

For the measurement of perceived behavioral control, a five-point "unipolar Likert scale from (0) strongly disagree to (4) strongly agree" was used. The statement was formed as follows: In my view, law enforcement is sufficient in the regions to control rural resident's activities. For the indirect assessment of perceived behavioral control, control beliefs $\left(\mathrm{cb}_{\mathrm{i}}\right)$ were assessed on a Likert scale ranging from (0) strongly disagree to (4) strongly agree, while $\mathrm{p}$ was measured on a scale ranging from (0) strongly disagree to (4) strongly agree.

\subsection{Analysis Methods}

Descriptive statistics were used to present the results, and "Pearson's correlation coefficients and regression analysis were chosen for interpretation". The Pearson correlation coefficients are used in statistics to measure how strong a relationship is between two variables. A value of 0 demonstrates that there is no correlation between the two variables. A value higher than 0 describes a positive relationship and a value less than 0 indicates a negative relationship. Regression analyses investigate the relationship between dependent and independent variables. 
To determine the relationship between dependent variables (attitude, descriptive norms, perceived behavioral control, behavioral intention) and independent variables $\left(\sum \mathrm{bs}_{\mathrm{i}} \mathrm{Oe}_{\mathrm{i}}\right.$, $\sum \mathrm{dnb}_{\mathrm{i}} \mathrm{iwr}_{\mathrm{i}}$, and $\sum \mathrm{cb}_{\mathrm{i}} \mathrm{pc}_{\mathrm{i}}$ ), a linear relationship was presumed (as mentioned in the mathematical formulation of TPB). Therefore, a multiple linear regression technique was used to analyze the data. P-values were used to interpret the significance level of regression analysis and coefficients. $\beta$ weights and $t$-values were used to interpret the results. $\mathrm{R}^{2}$ was applied for the evaluation of the explanatory power of the regression analysis. F-test was used for the assessment of the overall significance level of the models. Data analysis was performed using "Microsoft Excel for Windows version 19 and SPSS ver. 25 software".

\section{Results}

\subsection{Background Factors}

The survey was conducted with 207 interviewers, 92 percent of whom were males and 8 percent were females. the detail of background factors is presented in Table 2.

Table 2. Demographic survey of rural residents in protected areas of northern Pakistan.

\begin{tabular}{|c|c|c|c|c|c|c|c|}
\hline & & $\begin{array}{l}\text { Gilgit } \\
(n=65)\end{array}$ & $\begin{array}{l}\text { Skardu } \\
(n=73)\end{array}$ & $\begin{array}{l}\text { Astore } \\
(n=69)\end{array}$ & $\begin{array}{c}\text { Total } \\
(n=207)\end{array}$ & $\begin{array}{l}\text { Chi-Square } \\
\text { Value }\left(X^{2}\right)\end{array}$ & $p$-Value \\
\hline \multirow{5}{*}{ Age } & Less than 22 years & $11 \%$ & $21 \%$ & $14 \%$ & $15 \%$ & \multirow{5}{*}{$X^{2}=6.62$} & \multirow{5}{*}{0.577} \\
\hline & 23 to 35 years & $14 \%$ & $16 \%$ & $19 \%$ & $16 \%$ & & \\
\hline & 36 to 50 years & $38 \%$ & $25 \%$ & $32 \%$ & $32 \%$ & & \\
\hline & 51 to 65 years & $17 \%$ & $18 \%$ & $22 \%$ & $19 \%$ & & \\
\hline & 66 and Above & $20 \%$ & $21 \%$ & $13 \%$ & $18 \%$ & & \\
\hline \multirow{3}{*}{$\begin{array}{l}\text { Duration of } \\
\text { Residence }\end{array}$} & 0 to 20 years & $15 \%$ & $22 \%$ & $19 \%$ & $19 \%$ & \multirow{3}{*}{$X^{2}=2.01$} & \multirow{3}{*}{0.732} \\
\hline & 21 to 40 years & $51 \%$ & $51 \%$ & $45 \%$ & $49 \%$ & & \\
\hline & 41 and above & $34 \%$ & $27 \%$ & $36 \%$ & $32 \%$ & & \\
\hline \multirow{5}{*}{ Education } & Less than Primary & $35 \%$ & $24 \%$ & $22 \%$ & $27 \%$ & \multirow{5}{*}{$X^{2}=19.33$} & \multirow{5}{*}{0.012 * } \\
\hline & Primary & $16 \%$ & $30 \%$ & $12 \%$ & $19 \%$ & & \\
\hline & High School & $19 \%$ & $13 \%$ & $24 \%$ & $18 \%$ & & \\
\hline & Middle & $23 \%$ & $18 \%$ & $35 \%$ & $26 \%$ & & \\
\hline & College & $7 \%$ & $15 \%$ & $8 \%$ & $10 \%$ & & \\
\hline \multirow{3}{*}{ Family Size } & $1-4$ person & $15 \%$ & $15 \%$ & $22 \%$ & $17 \%$ & \multirow{3}{*}{$X^{2}=4.21$} & \multirow{3}{*}{0.377} \\
\hline & 5-10 person & $60 \%$ & $54 \%$ & $45 \%$ & $53 \%$ & & \\
\hline & 11 and above & $25 \%$ & $31 \%$ & $34 \%$ & $30 \%$ & & \\
\hline $\begin{array}{l}\text { Government } \\
\text { Assistance }\end{array}$ & Yes & $20 \%$ & $36 \%$ & $25 \%$ & $27 \%$ & $X^{2}=4.55$ & 0.102 \\
\hline Profession & $\begin{array}{l}\text { Small-scale } \\
\text { Agriculture }\end{array}$ & $83 \%$ & $77 \%$ & $83 \%$ & $81 \%$ & $X^{2}=1.14$ & 0.565 \\
\hline
\end{tabular}

Based on the feedback of the open-ended question about the participants' opinions on deforestation, $86 \%$ of participants reported negative beliefs, including $42 \%$ people cannot work, $20 \%$ people claimed that government does not pay a royalty for the properties, $11 \%$ think an increase in unemployment, and $10 \%$ thinks that usage of firewood is prohibited. Only 14\% mentioned just negative values. Respondents' beliefs categorized into negative values including restrictions and positive values including forest protection, relationship between education and profession, education and government assistance, Duration of Residence and government assistance, Age and government assistance, and found that the regression relationship is significant and multicollinearity is less than 5 . So, these re- 
sults indicate that there is an influence of these variables regarding deforestation if it is from the government sector or local communities [72].

\subsection{Components of Theory of Planned Behavior}

\subsubsection{Components of Behavioral Intention}

The majority of the participants (46\%) had thought to carry out the behavior in question, while $23 \%$ of them declared that it is an illegal activity to deforest. Attitude toward performing behavior was $59 \%$. At the same time, descriptive norms for the respondent's views toward other people were $42 \%$ that were engaging in illegal activities. As far as PBC is concerned, $47 \%$ of respondents were not satisfied with the performance of law enforcement.

\subsubsection{Components of Attitude}

Most of the participants (61\%) believed that the replacement of forests with smallscale agriculture will provide food for the family (agree and strongly agree on the "bipolar Likert scale"). With regards to other important beliefs that categorized the respondents are livelihood $(82 \%)$, however, respondents' beliefs toward replacing forest with tourism were adverse (Figure 4a). As far as outcome evaluation is concerned, $94 \%$ of the participants perceived that provide food to the family is important or very important " 3 and 4 on the bipolar Likert scale", while only $28 \%$ of the respondents stated that, for them, increase livelihood is of some importance.

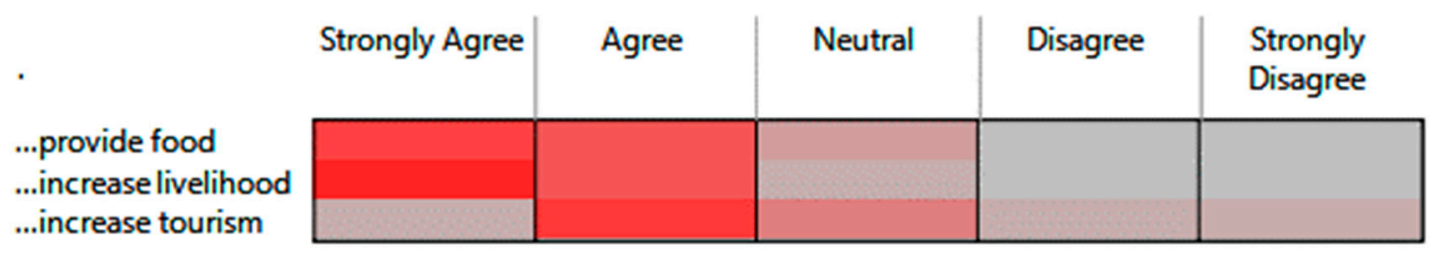

(a)

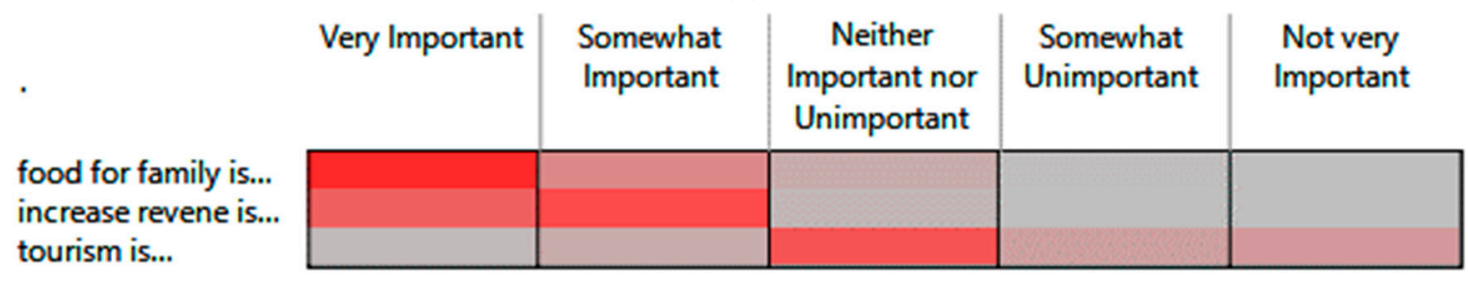

(b)

$0 \%$ to $20 \%$

$21 \%$ to $40 \%$

$41 \%$ to $60 \%$

$61 \%$ to $80 \%$

$81 \%$ to $100 \%$

Figure 4. $(\mathbf{a}, \mathbf{b})$ Evaluating the percentage of components of attitude (behavioral belief and outcome evaluation).

The results obtained from Pearson correlation coefficients described that belief-assessment $\left(b_{i} e_{i}\right)$ had a relatively strong association with the direct measurement of attitude (the values of Pearson coefficient lie between 0.2 and 0.4 ), with the notable exception of increasing tourism (see Table 3). The regression analysis verified the relationship between endogenous variable attitude and the exogenous variables $b_{i} e_{i}$ : the $\beta$-tourism coefficient was not found significant, whilst the $\beta$-coefficient for all other exogenous variables was significant. 
Table 3. Regression analysis to predict Attitude (dependent variable) from beliefs-evaluation (independent variables) Pearson correlation coefficients between $b_{i} e_{i}$ and Attitude $\left(F=14.671, R^{2}=0.178\right.$ and significance level $\left.=0.000\right)$.

\begin{tabular}{cccc}
\hline Beliefs $\times$ Outcome Evaluation (Biei) & Correlations Coefficients (r) & B-Coefficients & t-Values \\
\hline Provide food $\times$ food for family & $0.396^{* *}$ & $0.297^{* *}$ & 3.838 \\
Increase livelihood $\times$ increase revenue is & $0.327^{* *}$ & $0.138^{* *}$ & 1.767 \\
Increase tourism $\times$ tourism is & $0.223^{*}$ & 0.069 & 0.984 \\
\hline
\end{tabular}

** significant for $p \leq 0.01$. * significant for $p \leq 0.05$.

\subsubsection{Components of Descriptive Norm}

With regards to the perception of other people, it was perceived (78\%, say Yes) rural inhabitants replace the secondary forest with small-scale agriculture. Respondents generally confirmed their most people ( $85 \%$ ) have illegal activities in the forest (Figure 5).

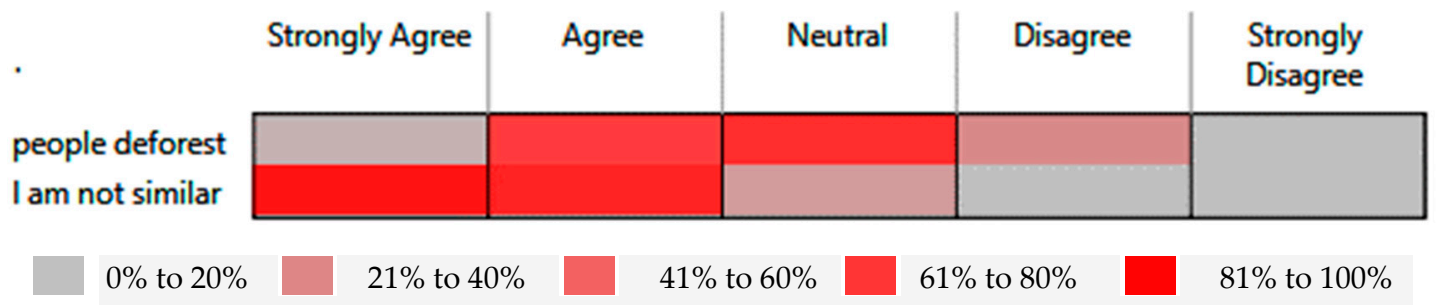

Figure 5. Percentage distribution of descriptive beliefs on the protection of forest.

By assessing correlation coefficients of descriptive normative beliefs $\left(\mathrm{dnb}_{\mathrm{i}}\right)$ and identification with the referent $\left(\mathrm{iwr}_{\mathrm{i}}\right)$, the descriptive norm was found correlated with these two products. The regression results demonstrated 20 percent of the variation in descriptive norm that confirmed illegal activities of the people in the region (Table 4).

Table 4. Multicollinearity among variables.

\begin{tabular}{cccccc}
\hline Model & B & $\mathbf{t}$ & Sig & $\mathbf{R}^{2}$ & Multicollinearity \\
\hline Duration of Residence and Age & 0.801 & 12.779 & $0.000^{*}$ & 0.642 & VIF $<1$ \\
Govt Assistance and Agriculture & 0.789 & 12.252 & $0.000^{*}$ & 0.623 & VIF $<1$ \\
Education and Agriculture & 0.661 & 8.411 & $0.000^{*}$ & 0.437 & VIF $<1$ \\
Education and Govt Assistance & 0.663 & 8.445 & $0.000^{*}$ & 0.439 & VIF $<1$ \\
Duration of Residence and Govt Assistance & 0.797 & 12.582 & $0.000^{*}$ & 0.635 & VIF $<1$ \\
Age and Govt Assistance & 0.789 & 12.252 & $0.000^{*}$ & 0.623 & VIF $<1$ \\
\hline
\end{tabular}

$$
{ }^{*} p<0.000 \text {. }
$$

\subsubsection{Components of PBC}

The statement on unsuitable legislation was supported by a majority of respondents, while the power of this belief to impede law enforcement was also perceived as high. Majority of respondents agreed without suitable training illegal behavior of residents would not stop (Figure 6a,b).

With regards to the evaluation of control belief $x$ perceived power to influence products $\left(\mathrm{cb}_{\mathrm{i}} \mathrm{p}_{\mathrm{i}}\right)$, it was found that both products were correlated with the PBC (see Table 5). However, insufficient legislation demonstrated a major factor affecting the perceived power of control. Both the Pearson correlation coefficient and the regression analysis results demonstrated that insufficient legislation as well as unsuited training significantly predicted PBC. 


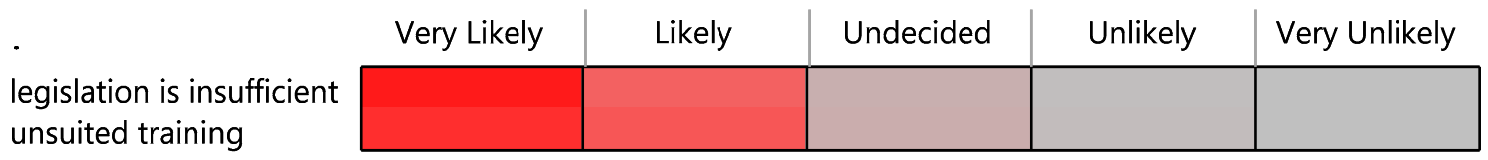

(a)

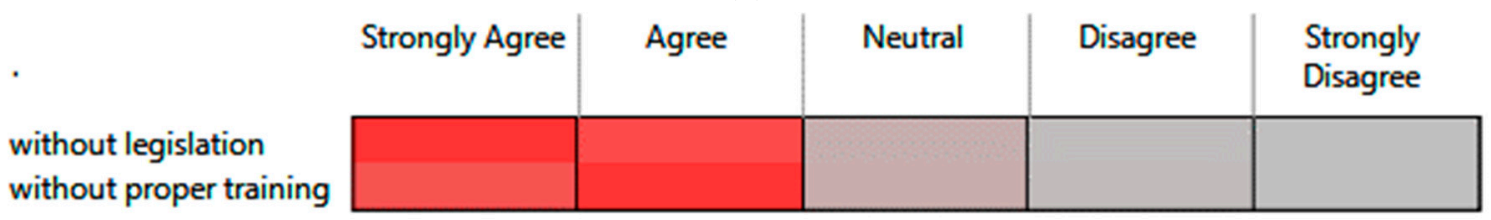

(b)

\section{\begin{tabular}{l|l|l|l|}
\hline $0 \%$ to $20 \%$ & $21 \%$ to $40 \%$ & $41 \%$ to $60 \%$ & $61 \%$ to $80 \%$
\end{tabular}}

Figure 6. (a,b): Percentage distribution of control beliefs (a) and compliance with the beliefs (b) in law enforcement to protect the forest.

Table 5. Regression analysis to predict perceived behavior control (dependent variable) from beliefs-evaluation (independent variables) Pearson correlation coefficients between biei and attitude $\left(F=37.679, R^{2}=0.270\right.$ and significance level $=$ 0.000).

\begin{tabular}{cccc}
\hline Control Beliefs $\left(\mathbf{c b}_{\mathbf{i}}\right) \times$ Power of Control Factors $\left(\mathbf{p c}_{\mathbf{i}}\right)$ & Correlations Coefficients $(\mathbf{r})$ & B-Coefficients & $\mathbf{t}$-Values \\
\hline Legislations insufficient $\times$ without legislation & $0.501^{* *}$ & $0.401^{* *}$ & 5.425 \\
Training of personnel unsuited $\times$ without proper training & $0.405^{* *}$ & $0.170^{* *}$ & 2.305 \\
\hline
\end{tabular}

** significant for $p \leq 0.01$.

\subsection{Factors Predicting the Rural Residents' Motivations Towards Deforestation}

The components of the theory of planned behavior-attitude, DN, and perceived behavior control-had shown strong associations with behavioral intention. Furthermore, the sums of all three products $\left(\sum \mathrm{b}_{\mathrm{i}} \mathrm{e}_{\mathrm{i}}, \sum \mathrm{nb}_{\mathrm{i}} \mathrm{mc}_{\mathrm{i}}\right.$, and $\left.\sum \mathrm{cb}_{\mathrm{i}} \mathrm{p}_{\mathrm{i}}\right)$ had a positive correlation with behavioral intention. Since all the variables had positive Pearson's correlation coefficients with behavioral intention (significant level of all variables $=p \leq 0.01$ ), none of the variables was excepted from the linear regression analysis that was proposed to explain the behavioral intention (Table 6).

Table 6. TPB (Theory of planned behavior) model explaining the Pearson's correlation coefficients.

\begin{tabular}{|c|c|c|c|c|c|c|c|c|c|}
\hline & Mean & Standard Deviation & BI & ATT & $\sum \mathbf{b s}_{\mathbf{i}} \mathbf{o e}_{\mathbf{i}}$ & DN & $\sum \mathrm{dnb}_{\mathrm{i}} \mathrm{irw}_{\mathrm{i}}$ & PBC & $\sum \mathrm{cb}_{\mathrm{i}} \mathrm{pc}_{\mathrm{i}}$ \\
\hline BI & 3.32 & 0.740 & 1.000 & & & & & & \\
\hline ATT & 3.53 & 0.621 & $0.611^{* *}$ & 1.000 & & & & & \\
\hline$\sum \mathbf{b s}_{\mathbf{i}} \mathbf{o e}_{\mathbf{i}}$ & 11 & 2.388 & $0.276^{* *}$ & $0.413 * *$ & 1.000 & & & & \\
\hline DN & 3.14 & 0.770 & $0.511^{* *}$ & $0.326^{* *}$ & $0.222 * *$ & 1.000 & & & \\
\hline$\sum \mathrm{dnb}_{\mathrm{i}} \mathrm{irw}_{\mathbf{i}}$ & 10.00 & 4.211 & $0.508^{* *}$ & $0.359 * *$ & $0.333^{* *}$ & $0.455^{* *}$ & 1.000 & & \\
\hline PBC & 3.29 & 0.785 & $0.539^{* *}$ & $0.334^{* *}$ & $0.113 *$ & $0.391^{* *}$ & $0.204^{* *}$ & 1.000 & \\
\hline$\sum \mathrm{cb}_{\mathrm{i}} \mathbf{p c}_{\mathrm{i}}$ & 11.442 & 3.067 & $0.458^{* *}$ & $0.291 * *$ & $0.310^{* *}$ & $0.197 *$ & $0.381 * *$ & $0.508^{* *}$ & 1.000 \\
\hline
\end{tabular}

** significant for $p \leq 0.01$. ${ }^{*}$ significant for $p \leq 0.05$.

Through the evaluation of multiple linear regression, all possible models to explain behavioral intention were examined. (Table 7). "The standardized regression coefficients (and t-values) of so-called basic model, having as explanatory variables attitude, descriptive norm, and perceived behavioral control, demonstrated that all of three variables had high explanatory power in behavioral intention variation. The basic model was also statistically significant $(p \leq 0.01)$ and explained $56 \%\left(R^{2}=0.552\right)$ of the total variation of the intention". 
Table 7. Regression analysis explaining the economic motives of rural residents toward behavioral intention (t-values and $\beta$-coefficients).

\begin{tabular}{|c|c|c|c|c|c|c|c|}
\hline \multirow{2}{*}{ Variables } & \multicolumn{6}{|c|}{$\beta$-Coefficients (t-Values) } & \multirow{2}{*}{ Model Features } \\
\hline & ATT & $\mathrm{DN}$ & PBC & $\sum \mathbf{b s}_{\mathbf{i}} \mathbf{o e}_{\mathbf{i}}$ & $\sum \mathrm{dnb}_{\mathbf{i}} \mathrm{irw}_{\mathbf{i}}$ & $\sum \mathrm{cb}_{\mathrm{i}} \mathrm{pc}_{\mathrm{i}}$ & \\
\hline Basic model & $0.436 * *(8.390)$ & $0.256^{* *}(4.887)$ & $0.295^{* *}(5.623)$ & - & - & - & $\begin{array}{c}F=83.455 \\
\text { Significance Level }=0.000 \\
\mathrm{R}^{2}=0.552\end{array}$ \\
\hline Model 1 & $0.429^{* *}(8.333)$ & $0.318^{* *}(6.339)$ & - & - & - & $0.270^{* *}(5.447)$ & $\begin{array}{c}F=82.201 \\
\text { Significance Level }=0.000 \\
R^{2}=0.548\end{array}$ \\
\hline Model 3 & $0.388 * *(7.592)$ & - & $0.348^{* *}(7.153)$ & - & $0.297^{* *}(6.047)$ & - & $\begin{array}{c}F=91.905 \\
\text { Significance Level }=0.000 \\
R^{2}=0.576\end{array}$ \\
\hline Model 4 & - & $0.321^{* *}(5.428)$ & $0.395^{* *}(6.810)$ & $0.160 *(2.927)$ & - & - & $\begin{array}{c}F=49.282 \\
\text { Significance Level }=0.000 \\
R^{2}=0.421\end{array}$ \\
\hline Model 6 & - & - & - & $0.059 *(0.955)$ & $0.375^{* *}(5.915)$ & $0.297^{* *}(4.717)$ & $\begin{array}{c}F=35.313 \\
\text { Significance Level }=0.000 \\
R^{2}=0.343\end{array}$ \\
\hline Model 7 & - & - & $0.449^{* *}(8.553)$ & $0.098 *(1.791)$ & $0.384^{* *}(6.925)$ & - & $\begin{array}{c}F=58.583 \\
\text { Significance Level }=0.000 \\
R^{2}=0.464\end{array}$ \\
\hline
\end{tabular}

** significant for $p \leq 0.01 .{ }^{*}$ significant for $p \leq 0.05$. 
However, attitude was the most powerful component to explain the behavior intentions with highest $\beta=0.436$, followed by descriptive norms $\beta=0.256$ and perceived behavioral control $\beta=0.295$ (Figure 7).

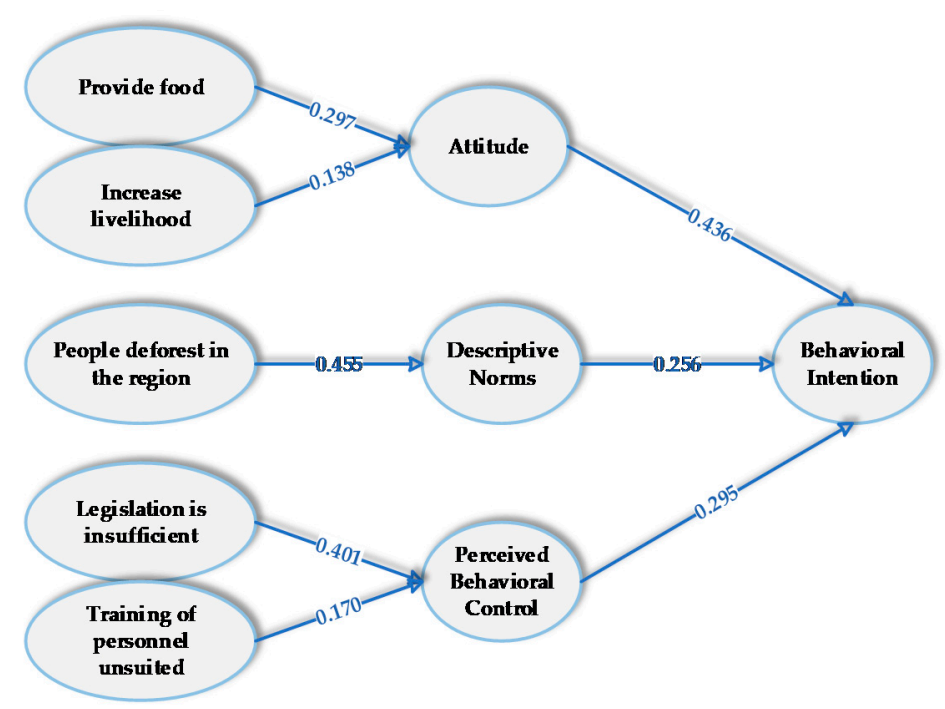

Figure 7. $\beta$-coefficient explaining the factors affecting behavioral intention.

Other analyzed models had the explanatory power in explaining the total variation of the behavioral intention ( $\mathrm{R}^{2}$ ranking between 0.576 and 0.343$)$.

\section{Discussion}

Ajzen's theory of planned behavior suggests that attitude, norms, and perceived behavioral control are better predictors to explain an individual's behavior [51]. In this research, a preliminary exploration of behavior toward economic incentive for deforestation in the study region was conducted using the theory of planned behavior as a framework for structuring our analysis. The findings of the study suggest that the level of education influenced respondent's behavioral intention to deforest for economic incentive. The present study explored that attitude, descriptive norm, and perceived behavior control may be good predictors to investigate the behaviors.

The analysis of the regression models has demonstrated that attitude was the major factor to explain behavioral intention. Perceived behavioral control was followed closely by descriptive norms, which verified the high power of influence. The PBC generally has the characteristic of high power, which is confirming by the other studies [73-79]. Besides these components, intention to deforest with small-scale agriculture was also high because of unsuited law effort in the region.

With regards to belief-based evaluation, the major item explaining the attitude was food for family, followed by an increased livelihood. In the context of Pakistan, the influence of these two factors is due to rural residents' reliance on natural resources. Interestingly, tourism was not perceived as an important factor. This could be due to mostly residents want to focus on agricultural activities and especially on family food. Descriptive norms were highly influenced by the respondent's behavior toward other people. Unlike other studies that stated perceived behavioral control might be a good predictor of behavior (e.g., [80-83], we found that people's perception of law enforcement did not affect their behavior. Rural resident's view of law enforcement might not be sufficient to avoid negative behavior, as the activities carried out involve the use of resources vital to the livelihoods of local communities [9,84-86].

Regarding that most rural residents are involved in agrarian activities, their main complaint was that they were prohibited from substituting secondary forests for smallscale agriculture, which impeded their work and livelihood. This feeling was expressed in 
negative attitudes toward forest conservation, as well as negative behavior, as some of the residents replacing secondary forests with small-scale farming.

Deforestation by residents of the area is a great challenge for forest management because reconciling land use and preservation of ecosystems inside the region requires a preventative measure to ensure the protection of remaining fragments without affecting the livelihoods of inhabitants.

The current research did not deal with all of the theory of planned behavior components (particularly, exclude the actual behavior and SN and explore the general element of PBC and DN related to the economic incentive for deforestation), attempting to prevent the use of the basic theory of planned behavior framework and complete analysis of structural equations modeling or multivariate regression. However, it identifies areas to be addressed by forestry managers to change the behavior of residents in relation to important conservation issues of deforestation.

There should be a prosecution of corrupt government officials in charge of the forestry laws and policies along with illegal loggers. Environmental awareness should be made accessible to the general public about the devastating consequences of deforestation on people and society at large. The government should embark on a program of tree planting by enlightening the public to fathom that we have only one earth. Government, Nongovernmental organizations, and spirited individuals should organize an enlightenment program on the impacts of climate change. The government should add more effort to the poverty eradication program, and the educated unemployed youths should be accorded employment. To curb the rate of deforestation, a skills training system should be coordinated for rural women dwellers and the uneducated youth. In conclusion, therefore, it is necessary to recognize and introduce successful ways of addressing the daily needs of the communities. The emphasis needs to be placed on seeking alternative energy sources, sustainable agricultural practices, diversifying income sources, and supporting rural development for young people and disadvantaged community members. In order to allow communities to engage actively in decision-making processes aimed at conserving the forest and improving the livelihoods of rural communities, forestry education and extension should be geared toward institutional strengthening at the local level.

\section{Conclusions}

The economic benefits include the provision of subsidies for forest products, an enhanced system of taxes on exploited forest goods, the procurement of well-monitored hunting licenses, alternative job opportunities, credit provision, and a limited ban on round $\log$ exports in northern areas of Pakistan. The study suggests that the level of education influenced the respondent's behavioral intention to deforest for economic incentive. The attitude, descriptive norm, and perceived behavior control may be good predictor to investigate the behaviors. Besides these components, the intention to deforest with small-scale agriculture was also high because of unsuited law efforts in the region. As far as outcome evaluation is concerned, $94 \%$ of the participants perceived that provide food to family is an important or very important component of livelihood. Socio-economic factors that affect the forest, such considerations are profoundly rooted in the everyday needs of the communities as regards forest products that meet the increasing population rather than knowledge of the degradation and its implications of forest resources.

However, insufficient legislation demonstrated a major factor that is affecting the perceived power of control. Both the Pearson correlation coefficient and the regression analysis demonstrated that insufficient legislation as well as unsuited training demonstrates that Human activities are environmentally hazardous in combination with our daily work and actions at home, in industry, and even in agriculture, endanger the stability of the climate and the ecological balance. All these human actions endanger nature. Adequate economic incentives can be an important tool for reducing deforestation. 
Author Contributions: S.U., A.A., R.S.N. and M.M.W. conceptualized the idea of the study design; R.S.N. and W.A. contributed to data collection and formal analysis; S.U., A.A. and R.S.N. performed the statistical analysis and wrote the manuscript; S.U., R.S.N. and M.M.W. edited and reviewed the manuscript; T.G. supervised and gave the conceptual insight. All authors have read and agreed to the published version of the manuscript.

Funding: This study has not received any funding.

Acknowledgments: Authors acknowledge the efforts of Central Karakoram National Park and staff for helping in data collection.

Conflicts of Interest: The authors declared no conflict of interest.

\section{References}

1. Durand, L.; Lazos, E. The Local Perception of Tropical Deforestation and its Relation to Conservation Policies in Los Tuxtlas Biosphere Reserve, Mexico. Hum. Ecol. 2008, 36, 383-394. [CrossRef]

2. Duguma, L.A.; Atela, J.; Minang, P.A.; Ayana, A.N.; Gizachew, B.; Nzyoka, J.; Bernard, F. Deforestation and Forest Degradation as an Environmental Behavior: Unpacking Realities Shaping Community Actions. Land 2019, 8, 26. [CrossRef]

3. Alcocer-Rodríguez, M.; Arroyo-Rodríguez, V.; Galán-Acedo, C.; Cristóbal-Azkarate, J.; Asensio, N.; Rito, K.F.; Hawes, J.E.; Veà, J.J.; Dunn, J.C. Evaluating extinction debt in fragmented forests: The rapid recovery of a critically endangered primate. Anim. Conserv. 2020, 1-12. [CrossRef]

4. Gogoi, B.; Nath, T.; Kashyap, D.; Sarma, S.; Kalita, R. Sustainable agriculture, forestry and fishery for bioeconomy. In Current Developments in Biotechnology and Bioengineering; Elsevier Science: Amsterdam, The Netherlands, 2020; pp. 349-371.

5. Osorio-González, C.S.; Suralikerimath, N.; Hegde, K.; Brar, S.K. Sustainability of Ecosystem Services (ESs). Sustainability 2020, 277-294. [CrossRef]

6. Quang, N.V.; Noriko, S. Forest Allocation Policy and Level of Forest Dependency of Economic Household Groups: A Case Study in Northern Central Vietnam. Small-Scale For. 2008, 7, 49-66. [CrossRef]

7. Adhikari, B.; Di Falco, S.; Lovett, J.C. Household characteristics and forest dependency: Evidence from common property forest management in Nepal. Ecol. Econ. 2004, 48, 245-257. [CrossRef]

8. Luna, T.O.; Zhunusova, E.; Günter, S.; Dieter, M. Measuring forest and agricultural income in the Ecuadorian lowland rainforest frontiers: Do deforestation and conservation strategies matter? For. Policy Econ. 2020, 111, 102034. [CrossRef]

9. Zeb, A.; Armstrong, G.W.; Hamann, A. Forest conversion by the indigenous Kalasha of Pakistan: A household level analysis of socioeconomic drivers. Glob. Environ. Chang. 2019, 59, 102004. [CrossRef]

10. Yiwen, Z.; Kant, S.; Dong, J.; Liu, J. How communities restructured forest tenure throughout the top-down devolution reform: Using the case of Fujian, China. For. Policy Econ. 2020, 119, 102272. [CrossRef]

11. Puri, L.; Nuberg, I.; Ostendorf, B.; Cedamon, E. Locally Perceived Social and Biophysical Factors Shaping the Effective Implementation of Community Forest Management Operations in Nepal. Small-Scale For. 2020, 19, 291-317. [CrossRef]

12. Jannat, M.; Hossain, M.K.; Uddin, M. Socioeconomic factors of forest dependency in developing countries: Lessons learned from the Bandarban hill district of Bangladesh. Am. J. Pure Appl. Sci. 2020, 2, 77-84.

13. Sirivongs, K.; Tsuchiya, T. Relationship between local residents' perceptions, attitudes and participation towards national protected areas: A case study of Phou Khao Khouay National Protected Area, central Lao PDR. For. Policy Econ. 2012, 21, 92-100. [CrossRef]

14. Ullah, S.; Gang, T.; Rauf, T.; Sikandar, F.; Liu, J.Q.; Noor, R.S. Identifying the socio-economic factors of deforestation and degradation: A case study in Gilgit Baltistan, Pakistan. GeoJournal 2020, 1-14. [CrossRef]

15. Brankov, J.; Jojić, G.T.; Pešić, A.M.; Petrović, M.D.; Tretiakova, T.N. Residents' Perceptions of Tourism Impact on Community in National Parks in Serbia. Eur. Countrys. 2019, 11, 124-142. [CrossRef]

16. Walde, J.; Huy, D.T.; Tappeiner, U.; Tappeiner, G. A protected area between subsistence and development. Int. J. Commons 2019, 13, 175. [CrossRef]

17. Badola, R.; Barthwal, S.; Hussain, S.A. Attitudes of local communities towards conservation of mangrove forests: A case study from the east coast of India. Estuarine Coast. Shelf Sci. 2012, 96, 188-196. [CrossRef]

18. John, F.A.V.S.; Edwards-Jones, G.; Jones, J.P.G. Conservation and human behaviour: Lessons from social psychology. Wildl. Res. 2011, 37, 658-667. [CrossRef]

19. Khan, W.; Hore, U.; Mukherjee, S.; Mallapur, G. Human-crocodile conflict and attitude of local communities toward crocodile conservation in Bhitarkanika Wildlife Sanctuary, Odisha, India. Mar. Policy 2020, 121, 104135. [CrossRef]

20. Al Idrus, A.; Syukur, A.; Zulkifli, L. The livelihoods of local communities: Evidence success of mangrove conservation on the coastal of East Lombok Indonesia. AIP Conf. Proc. 2019, 2199, 050010.

21. Garekae, H.; Lepetu, J.; Thakadu, O.T.; Sebina, V.; Tselaesele, N. Community Perspective on State Forest Management Regime and its Implication on Forest Sustainability: A Case Study of Chobe Forest Reserve, Botswana. J. Sustain. For. 2020, 39, 692-709. [CrossRef] 
22. Waylen, K.A.; Fischer, A.; McGowan, P.J.K.; Thirgood, S.J.; Milner-Gulland, E.J. Effect of Local Cultural Context on the Success of Community-Based Conservation Interventions. Conserv. Biol. 2010, 24, 1119-1129. [CrossRef] [PubMed]

23. Dhakal, B.; Kattel, R.R. Effects of global changes on ecosystems services of multiple natural resources in mountain agricultural landscapes. Sci. Total Environ. 2019, 676, 665-682. [CrossRef] [PubMed]

24. Musavengane, R.; Kloppers, R. Social capital: An investment towards community resilience in the collaborative natural resources management of community-based tourism schemes. Tour. Manag. Perspect. 2020, 34, 100654. [CrossRef]

25. Avtar, R.; Tsusaka, K.; Herath, S. REDD+ Implementation in Community-Based Muyong Forest Management in Ifugao, Philippines. Land 2019, 8, 164. [CrossRef]

26. Shahbaz, B.; Ali, T.; Suleri, A.Q. A Critical Analysis of Forest Policies of Pakistan: Implications for Sustainable Livelihoods. Mitig. Adapt. Strat. Glob. Chang. 2007, 12, 441-453. [CrossRef]

27. Nandigama, S. Performance of success and failure in grassroots conservation and development interventions: Gender dynamics in participatory forest management in India. Land Use Policy 2020, 97, 103445. [CrossRef]

28. Sheikh, Y.; Ibrar, M.; Iqbal, J. Impact of Joint Forest Management on Rural Livelihoods in the Kalam and Siran Forest Divisions, Khyber Pakhtunkhwa Pakistan. Glob. Reg. Rev. 2019, 4, 225-237. [CrossRef]

29. Payne, D.; Snethlage, M.; Geschke, J.; Spehn, E.M.; Fischer, M. Nature and People in the Andes, East African Mountains, European Alps, and Hindu Kush Himalaya: Current Research and Future Directions. Mt. Res. Dev. 2020, 40, A1. [CrossRef]

30. Kabir, M.; Hameed, S.; Ali, H.; Bosso, L.; Din, J.U.; Bischof, R.; Redpath, S.; Nawaz, M.A. Habitat suitability and movement corridors of grey wolf (Canis lupus) in Northern Pakistan. PLoS ONE 2017, 12, e0187027. [CrossRef]

31. Hussain, M.; Butt, A.R.; Uzma, F.; Ahmed, R.; Rehman, A.; Ali, M.U.; Ullah, H.; Yousaf, B. Divisional disparities on climate change adaptation and mitigation in Punjab, Pakistan: Local perceptions, vulnerabilities, and policy implications. Environ. Sci. Pollut. Res. 2019, 26, 31491-31507. [CrossRef]

32. Hussain, J.; Zhou, K.; Akbar, M.; Khan, M.Z.; Raza, G.; Ali, S.; Hussain, A.; Abbas, Q.; Khan, G.; Khan, M.; et al. Dependence of rural livelihoods on forest resources in Naltar Valley, a dry temperate mountainous region, Pakistan. Glob. Ecol. Conserv. 2019, 20, e00765. [CrossRef]

33. Ali, N.; Hu, X.; Hussain, J. The dependency of rural livelihood on forest resources in Northern Pakistan's Chaprote Valley. Glob. Ecol. Conserv. 2020, 22, e01001. [CrossRef]

34. Shahbaz, B.; Mbeyale, G.; Haller, T. Trees, trust and the state: A comparison of participatory forest management in Pakistan and Tanzania. J. Int. Dev. 2008, 20, 641-653. [CrossRef]

35. Ali, J.; Benjaminsen, T.A. Fuelwood, Timber and Deforestation in the Himalayas. Mt. Res. Dev. 2004, 24, 312-318. [CrossRef]

36. Macdonald, K.; Rudel, T.K. Sprawl and forest cover: What is the relationship? Appl. Geogr. 2005, 25, 67-79. [CrossRef]

37. Jeon, S.B.; Olofsson, P.; Woodcock, C.E. Land use change in New England: A reversal of the forest transition. J. Land Use Sci. 2014, 9, 105-130. [CrossRef]

38. Wang, H.; Qiu, F. Investigating the Impact of Agricultural Land Losses on Deforestation: Evidence from a Peri-urban Area in Canada. Ecol. Econ. 2017, 139, 9-18. [CrossRef]

39. de Freitas, D.; van Eeden, T.S.; Christie, L. A psychographic framework for determining South African consumers' green hotel decision formation: Augmenting the Theory of Planned Behaviour. J. Consum. Sci. 2020, 5, 1-18. Available online: https:/ / www.ajol.info/index.php/jfecs/article/view/195428 (accessed on 5 January 2021).

40. Pendrill, F.; Persson, U.M.; Godar, J.; Kastner, T. Deforestation displaced: Trade in forest-risk commodities and the prospects for a global forest transition. Environ. Res. Lett. 2019, 14, 055003. [CrossRef]

41. Pendrill, F.; Persson, U.M.; Godar, J.; Kastner, T.; Moran, D.; Schmidt, S.; Wood, R. Agricultural and forestry trade drives large share of tropical deforestation emissions. Glob. Environ. Chang. 2019, 56, 1-10. [CrossRef]

42. Murshed, M.; Ferdaus, J.; Rashid, S.; Tanha, M.M.; Islam, J. The Environmental Kuznets curve hypothesis for deforestation in Bangladesh: An ARDL analysis with multiple structural breaks. Energy Ecol. Environ. 2020, 1-22. [CrossRef]

43. Curtis, P.G.; Slay, C.M.; Harris, N.; Tyukavina, A.; Hansen, M.C. Classifying drivers of global forest loss. Science 2018, 361, 11081111. [CrossRef] [PubMed]

44. De Sy, V.; Herold, M.; Achard, F.; Avitabilie, V.; Baccini, A.; Carter, S.; Clevers, J.G.P.W.; Lindquist, E.; Pereira, M.; Verchot, L. Tropical deforestation drivers and associated carbon emission factors derived from remote sensing data. Environ. Res. Lett. 2019, 14, 094022. [CrossRef]

45. Doggart, N.; Morgan-Brown, T.; Lyimo, E.; Mbilinyi, B.; Meshack, C.K.; Sallu, S.M.; Spracklen, D.V. Agriculture is the main driver of deforestation in Tanzania. Environ. Res. Lett. 2020, 15, 034028. [CrossRef]

46. Diouf, B.; Miezan, E. The Biogas Initiative in Developing Countries, from Technical Potential to Failure: The Case Study of Senegal. Renew. Sustain. Energy Rev. 2019, 101, 248-254. [CrossRef]

47. Günşen, H.B.; Atmiş, E. Analysis of forest change and deforestation in Turkey. Int. For. Rev. 2019, 21, 182-194. [CrossRef]

48. Khan, A.M.; Hussain, A.; Siddique, S.; Khan, S.M.; Iqbal, A.; Ahmad, T.; Suliman, M.; Ali, G. Effects of deforestation on socio-economy and associated insect pests in district Swat, Pakistan. J. Entomol. Zool. Stud. 2017, 5, 36-42.

49. Ali, J.; Benjaminsen, T.A.; Hammad, A.A.; Dick, Ø.B. The road to deforestation: An assessment of forest loss and its causes in Basho Valley, Northern Pakistan. Glob. Environ. Chang. 2005, 15, 370-380. [CrossRef]

50. Ajzen, I. The theory of planned behavior. Organ. Behav. Hum. Decis. Process. 1991, 50, 179-211. [CrossRef] 
51. Ajzen, I.; Fishbein, M. The Influence of Attitudes on Behavior. In The Handbook of Attitudes; Albarracín, D., Johnson, B.T., Zanna, M.P., Eds.; Lawrence Erlbaum Associates Publishers: Hillsdale, NY, USA, 2005; pp. 173-221.

52. Stern, P.C. New Environmental Theories: Toward a Coherent Theory of Environmentally Significant Behavior. J. Soc. Issues 2000, 56, 407-424. [CrossRef]

53. Cialdini, R.B.; Petrova, P.K.; Goldstein, N.J. The hidden costs of organizational dishonesty. MIT Sloan Manag. Rev. $2004,45,67$.

54. Ajzen, I. The theory of planned behavior: Frequently asked questions. Hum. Behav. Emerg. Technol. 2020, 2, 314-324. [CrossRef]

55. Si, H.; Shi, J.-G.; Tang, D.; Wu, G.; Lan, J. Understanding intention and behavior toward sustainable usage of bike sharing by extending the theory of planned behavior. Resour. Conserv. Recycl. 2020, 152, 104513. [CrossRef]

56. Miniard, P.W.; Cohen, J.B. Modeling Personal and Normative Influences on Behavior. J. Consum. Res. 1983, 10, 169-180. [CrossRef]

57. Daxini, A.; Ryan, M.; O'Donoghue, C.; Barnes, A.P. Understanding farmers' intentions to follow a nutrient management plan using the theory of planned behaviour. Land Use Policy 2019, 85, 428-437. [CrossRef]

58. Popa, B.; Niță, M.D.; Hălălișan, A.F. Intentions to engage in forest law enforcement in Romania: An application of the theory of planned behavior. For. Policy Econ. 2019, 100, 33-43. [CrossRef]

59. Pakravan, M.H.; Maccarty, N. An Agent-Based Model for Adoption of Clean Technology Using the Theory of Planned Behavior. J. Mech. Des. 2021, 143, 021402. [CrossRef]

60. Liang, Y. Toward a Sustainable Online Q \& A Community Via Design Decisions Based on Individuals' Expertise: Evidence from Simulations. Ph.D. Thesis, Michigan State University, East Landing, MI, USA, 2020.

61. Ajzen, I.; Madden, T.J. Prediction of goal-directed behavior: Attitudes, intentions, and perceived behavioral control. J. Exp. Soc. Psychol. 1986, 22, 453-474. [CrossRef]

62. Rahman, U.H.F.B.; Zafar, M.K. Factors Influencing Uber Adoption in Bangladesh and Pakistan. Open Econ. 2020,3 , 86-97. [CrossRef]

63. Çoker, E.N.; van der Linden, S. Fleshing out the theory of planned of behavior: Meat consumption as an environmentally significant behavior. Curr. Psychol. 2020, 1-10. [CrossRef]

64. Ateş, H. Merging Theory of Planned Behavior and Value Identity Personal Norm Model to Explain Pro-Environmental Behaviors. Sustain. Prod. Consum. 2020, 24, 169-180. [CrossRef]

65. Fishbein, M.; Ajzen, I. Predicting and Changing Behavior: The Reasoned Action Approach; Taylor \& Francis Group: New York, NY, USA, 2011.

66. Nisson, C.; Earl, A. The Theories of Reasoned Action and Planned Behavior. Wiley Encycl. Health Psychol. 2020, 755-761. [CrossRef]

67. Ajzen, I.; Driver, B.L. Application of the Theory of Planned Behavior to Leisure Choice. J. Leis. Res. 1992, 24, 207-224. [CrossRef]

68. Zhang, Y.; Li, L. Intention of Chinese college students to use carsharing: An application of the theory of planned behavior. Transp. Res. Part F Traffic Psychol. Behav. 2020, 75, 106-119. [CrossRef]

69. Kellert, S.R. Nature and Childhood Development. Building for Life: Designing and Understanding the Human-Nature Connection; Island Press: Washington, DC, USA, 2005.

70. Kylkilahti, E.; Berghäll, S.; Autio, M.; Nurminen, J.; Toivonen, R.; Lähtinen, K.; Vihemäki, H.; Franzini, F.; Toppinen, A. A consumer-driven bioeconomy in housing? Combining consumption style with students' perceptions of the use of wood in multi-storey buildings. Ambio 2020, 49, 1943-1957. [CrossRef]

71. Ullah, F.; Saqib, S.E.; Ahmad, M.M.; Fadlallah, M.A. Flood risk perception and its determinants among rural households in two communities in Khyber Pakhtunkhwa, Pakistan. Nat. Hazards 2020, 104, 225-247. [CrossRef]

72. Hair, J.F., Jr.; Hult, G.T.M.; Ringle, C.M.; Sarstedt, M. A Primer on Partial Least Squares Structural Equation Modeling (PLS-SEM). J. Acad. Mark. Sci. 2017, 45, 616-632. [CrossRef]

73. Fielding, K.S.; McDonald, R.; Louis, W.R. Theory of planned behaviour, identity and intentions to engage in environmental activism. J. Environ. Psychol. 2008, 28, 318-326. [CrossRef]

74. Karppinen, H. Forest owners' choice of reforestation method: An application of the theory of planned behavior. For. Policy Econ. 2005, 7, 393-409. [CrossRef]

75. Masud, M.M.; Al-Amin, A.Q.; Junsheng, H.; Ahmed, F.; Yahaya, S.R.; Ahmed, S.; Banna, H. Climate change issue and theory of planned behaviour: Relationship by empirical evidence. J. Clean. Prod. 2016, 113, 613-623. [CrossRef]

76. Judge, M.; Warren-Myers, G.; Paladino, A. Using the theory of planned behaviour to predict intentions to purchase sustainable housing. J. Clean. Prod. 2019, 215, 259-267. [CrossRef]

77. Oteng-Peprah, M.; De Vries, N.; Acheampong, M. Households' willingness to adopt greywater treatment technologies in a developing country-Exploring a modified theory of planned behaviour (TPB) model including personal norm. J. Environ. Manag. 2020, 254, 109807. [CrossRef] [PubMed]

78. Iranmanesh, M.; Mirzaei, M.; Hosseini, S.M.P.; Zailani, S. Muslims' willingness to pay for certified halal food: An extension of the theory of planned behaviour. J. Islam. Mark. 2019, 11, 14-30. [CrossRef]

79. Yuriev, A.; Dahmen, M.; Paille, P.; Boiral, O.; Guillaumie, L. Pro-environmental behaviors through the lens of the theory of planned behavior: A scoping review. Resour. Conserv. Recycl. 2020, 155, 104660. [CrossRef]

80. Mintzer, V.J.; Schmink, M.; Lorenzen, K.; Frazer, T.K.; Martin, A.R.; Da Silva, V.M.F. Attitudes and behaviors toward Amazon River dolphins (Inia geoffrensis) in a sustainable use protected area. Biodivers. Conserv. 2015, 24, 247-269. [CrossRef]

81. Zubair, M.; Garforth, C. Farm Level Tree Planting in Pakistan: The Role of Farmers' Perceptions and Attitudes. Agrofor. Syst. 2006, 66, 217-229. [CrossRef] 
82. Mahmood, M.I.; Zubair, M. Farmer's Perception of and Factors Influencing Agroforestry Practices in the Indus River Basin, Pakistan. Small-Scale For. 2020, 19, 107-122. [CrossRef]

83. Tokede, A.; Banjo, A.; Ahmad, A.; Fatoki, O.; Akanni, O. Farmers' knowledge and attitude towards the adoption of agroforestry practices in Akinyele Local Government Area, Ibadan, Nigeria. J. Appl. Sci. Environ. Manag. 2020, 24, 1775-1780. [CrossRef]

84. De Boer, W.F.; Baquete, D.S. Natural resource use, crop damage and attitudes of rural people in the vicinity of the Maputo Elephant Reserve, Mozambique. Environ. Conserv. 1998, 25, 208-218. [CrossRef]

85. Miyamoto, M. Poverty reduction saves forests sustainably: Lessons for deforestation policies. World Dev. 2020, 127, 104746. [CrossRef]

86. Putraditama, A.; Kim, Y.-S.; Meador, A.J.S. Community forest management and forest cover change in Lampung, Indonesia. For. Policy Econ. 2019, 106, 101976. [CrossRef] 